Fastabiq: Jurnal Studi Islam

ISSN 2723-0228

Volume 1 Nomor 2 Nopember 2020

Halaman 120-131

\title{
RELASI MASJID DAN PASAR: KAJIAN SOSIOLOGI HUKUM TERHADAP KEBIJAKAN PENERAPAN PEMBATASAN SOSIAL BERSKALA BESAR SAAT PANDEMI COVID 19
}

\author{
Indra budi Jaya \\ Universitas Muhammadiyah Bandung \\ indrabj36@gmail.com
}

\begin{abstract}
Islam as a religion wants its people to always maintain a balance between religiosity (al din) and worldly problems (al dunya). The relationship between the two describes something that is separate but inseparable (harmony). However, for modern society, this condition often creates contradictions, this condition was seen at the time of the Covid 19 pandemic. The implementation of Large-Scale Social Restrictions by the government in an effort to overcome the spread of the impact of Covid 19 to the community by limiting activities in mosques and allowing activities in the market to continue in fact responded by the community differently. The methodology used is qualitative by using social policy analysis. This paper tries to examine social policies towards the application of large-scale social restrictions on mosques and markets. In this paper, the sociology of law theory is used, namely Law is a social engineering tool which emphasizes that law becomes the commander who must bring change to society. The results obtained in the research are that the community responds to the largescale social restriction policy differently, where the purpose of the policy is for the community to be expected to make changes by complying with the rules that have been set by the government, the conditions for rejection and various responses are caused by disharmony between implementation of policies with public awareness of the law.
\end{abstract}

Keyword : Policy, large-Scale Restrictions and the sociology of law.

\begin{abstract}
Abstrak
Islam sebagai agama mengkhendaki umatnya agar senantiasa menjaga keseimbangan antara religiusitas (al din) dan masalah keduniaan (al dunia). Hubungan keduanya menggambarkan sesuatu yang terpisah namun tidak bisa dipisahkan (harmoni). Namun bagi masyarakat modern kondisi tersebut seringkali justru menimbulkan pertentangan, kondisi tersebut nampak pada saat terjadinya pandemi Covid 19. Penerapan Pembatasan Sosial Berskala Besar oleh pemerintah dalam upaya penanggulangan penyebaran dampak Covid 19 kepada masyarakat dengan membatasi aktivitas di masjid dan membiarkan kegiatan di pasar tetap berjalan nyatanya direspon oleh masyarakat secara berbeda. Metodologi yang digunakan adalah kualitatif dengan menggunakan analisis kebijakan sosial, Tulisan ini mencoba menelaah kebijakan sosial terhadap penerapan pembatasan sosial berskala besar terhadap masjid dan pasar. Dalam penulisan ini dipergunakan teori sosiologi hukum yaitu Law is a tool social engineering yang menegaskan bahwa hukum menjadi panglima yang harus membawa perubahan terhadap masyarakat. Hasil yang diperoleh dalam penelitian adalah Masyarakat merespon kebijakan pembatasan sosial berskala besar tersebut secara berbeda, dimana tujuan kebijakan tersebut adalah untuk masyarakat diharapkan dapat melakukan perubahan dengan mematuhi aturan yang telah di tetapkan oleh pemerintah, kondisi penolakan dan respon beragam tersebut di sebabkan oleh ketidak harmonisannya antara penerapan kebijakan dengan kesadaran masyarakat terhadap hukum.
\end{abstract}

Kata Kunci : Kebijakan, Pembatasan Sosial Berskala Besar dan Sosiologi Hukum 


\section{PENDAHULUAN}

Menelaah relasi masjid dan pasar sebetulnya bukan lah sesuatu yang baru. Sejak jaman Nabi posisi masjid dan pasar sudah dijelaskan dalam sebuah hadits yang diriwayatkan dari Abu Hurairah, bahwa Nabi bersabda, "Negeri (tempat) yang paling dicintai Allah adalah pada masjid-masjidnya, dan tempat yang paling dimurkai Allah adalah pasar-pasarnya,"' (HR Muslim) ${ }^{1}$. Selintas kita akan menemukan posisi masjid dan pasar sebagai objek yang dipertentangkan, Namun rupanya hadits tersebut secara dialektis memiliki makna yang kemudian menjelaskan secara simbolis antara masjid dan pasar, Masjid sebagai simbol dari agama atau spiritualitas dan pasar sebagai simbol kepentingan ekonomi.

Relasi masjid dan pasar dalam tema yang lain dijelaskan secara terpisah namun tetap memiliki ikatan yang harmonis. Di dalam al-Quran hubungan antara masjid dan pasar terlihat jelas pada ayat yang mengatur tentang shalat jumat yaitu Al Quran Surat Al-Jumu'at ayat 9-10 yang berbunyi: "Wahai Orang-orang yang beriman! Apabila telah diseru untuk melaksanakan shalat pada hari Jum'at, maka segeralah kamu mengingat Allah dan tinggalkanlah jual beli. Yang demikian itu lebih baik bagimu jika kamu mengetahui" (Al-Jumu'at ayat 9). Selanjutnya "Apabila shalat telah selesai dilaksanakan, maka bertebaranlah kamu di muka bumi; carilah karunia Allah dan ingatlah Allah banyak-banyak agar kamu beruntung" (Al-Jumu'at ayat 10). Dari ayat tersebut diperoleh pengertian bahwa ketika datang waktu shalat maka setiap muslim wajib menunaikan shalat dan meninggalkan jual beli, dan setelah selesai di persilahkan untuk bertebaran di muka bumi untuk mencari rezeki, maka secara prinsip, islam mementingkan perlunya akhlak dalam aktivitas perniagaan.

Fungsi masjid dalam sejarahnya memang tidak hanya sekedar representasi religiusitas sebagaimana makna harfiahnya, tetapi memiliki makna yang lebih multifungsi. Pada masa Rasulullah Saw, masjid berfungsi sebagai sentra kegiatan-kegiatan pendidikan, yakni tempat pembinaan dan pembentukan karakter umat. Bahkan lebih strategis, pada masa Rasulullah Saw, masjid menjadi sentra kegiatan politik, ekonomi, sosial dan budaya umat. Itulah kemudian yang membuat hubungan manusia dengan masjid bagi umat islam sangat erat dan tidak bisa dipisahkan, walaupun dalam perkembangannya terjadi penyempitan makna fungsional masjid, Setidaknya bagi Sebagian masyarakat masjid diposisikan hanya sebagai tempat ritual peribadatan saja tidak lebih daripada iitu

Menurut Kuntowijoyo, Jika masjid ditunjuk sebagai sebuah tema yang mempersatukan, maksudnya tentu saja nabi ingin dengan jelas mengatakan dengan lambang yang kongkrit, eksistensial dan sekaligus struktural, tidak hanya esensi dan abtraksi. Demikian juga lambang pasar terasa lebih empiris dan menunjuk pada kekuatan sejarah yang nyata, yang menggerakan dunia modern ${ }^{2}$. Oleh karena itu, Kedudukan masjid sebagai pusat kehidupan umat islam tidak bisa dipisahkan dengan rutinitas kehidupan sehari-hari masyarakat. Kedudukan Masjid dalam islam secara historis dan kontekstual merupakan pilar utama dan terpenting dalam pembentukan pembentukan masyarakat islam. Masjid dalam fungsinya merupakan tempat yang bernilai kebajikan 
dan kemaslahatan umat, baik yang berdimensi ukhrawi maupun duniawi dalam sebuah garis kebijakan manajemen masjid. Nabi Muhammad SAW pun telah mencontohkan bahwa masjid memiliki multifungsi dalam membina dan mengurusi seluruh kepentingan umat, baik di bidang ekonomi, politik, sosial, pendidikan, militer dan lain sebagainya. ${ }^{3}$ Sedangkan pasar sebagai tempat transaksi jual beli antara pedagang dan penjual pembeli memiliki peran dan fungsi penting dalam kegiatan ekonomi masyarakat, dimana selain memiliki fungsi ekonomi yang memenuhi kebutuhan jual beli namun dapat dijadikan sebagai sarana untuk saling bertukar informasi antara penjual dan pembeli. Di dalam Pasar ditawarkan pula bentuk-bentuk kebudayaan yang lain dari kebudayaan masyarakat sekitar pasar tersebut. Kebudayaan itu sendiri adalah kompleks yang mencakup pengetahuan, kepercayaan, kesenian, moral, hukum, adat istiadat dan kemampuan-kemampuan serta kebiasaan-kebiasaan yang dapat oleh manusia sebagai anggota masyarakat. ${ }^{4}$

Pasar dan Masjid dalam perspektif Sosiologis memiliki kesamaan yaitu sebagai tempat berkumpulnya masyarakat, Namun secara fungsional dalam posisi tertentu seperti dipisahkan dalam makna duniawi dan ukhrawi yang tentu saja menyebabkan respon masyarakat berbeda terhadap permasalahan yang muncul melibatkan peran pasar dan masjid. Seperti bagaimana masyarakat merespon posisi eksistensi pasar dan masjid dimasa pandemi yang terjadi ditahun 2020 saat masyarakat dunia di gemparkan oleh penemuan virus Corona atau Severe Acute Resripatory Syindrome Coronavirus (SARS-CoV-2) yang umumnya masyarakat menyebutnya dengan sebutan virus corona yaitu virus yang menyerang sistem pernapasan pada manusia. Penyakit karena infeksi virus ini disebut Covid 19. Virus Corona bisa menyebabkan gangguan ringan pada sistem pernapasan, infeksi paru-paru berat, hingga kematian. ${ }^{5}$ Masjid dan pasar sebagai tempat yang memiliki peran strategis dalam kehidupan sehari-hari juga ikut terdampak karena penyebaran virus tersebut.

Banyak Negara di dunia termasuk Indonesia menerapkan kebijakan Pysical distancing ${ }^{6}$ seperti yang di anjurkan oleh WHO sebagai Organisasi Kesehatan dunia yang bertindak sebagai Koordinator Kesehatan umum internasional. Di Indonesia Pysical Distancing lebih dikenal dengan istilah Pembatasan Sosial berskala besar (PSBB) dengan harapan dapat menekan angka penularan COVID 19. Virus ini sejatinya memang pertama kali ditemukan di kota Wuhan negara Tiongkok pada Desember tahun 2019. Virus Covid 19 memiliki kemampuan menular cepat melalui droplet saat orang batuk ataupun bersin, Kekhawatiran tidak terkendalinya penularan menuntut pemerintah Indonesia untuk bergerak dan menentukan kebijakan secara cepat dan tepat, Pemerintah Indonesia secara resmi mengumumkan kasus pertama dua orang WNI Positif terkena Virus Corona pada 2 maret 2020. ${ }^{7}$ Oleh karena ditemukannya kasus positif virus Corona di Indonesia, maka pemerintah secara responsif melakukan penanganan dengan menerapkan kebijakan pembatasan aktivitas masyarakat, namun karena kultur dan kondisi yang berbeda dengan negara-negara lain yang menerapkan lockdown sepenuhnya, negara Indonesia memilih melakukan pembatasan sosial berskala besar 
dengan tetap membolehkan aktivitas warga sebagian namun jenih-jenis kegiatan seperti aktivitas keagamaan, Sekolah, aktivitas kantor dibatasi selama pandemi berlangsung.

Dalam Peraturan Menteri Kesehatan Republik Indonesia Nomor 9 Tahun 2020 Tentang Pedoman Pembatasan Sosial Berskala Besar Dalam Rangka Percepatan Penanganan Corona Virus Disease 2019 (Covid-19) Pasal 13 ayat 1 menyebutkan bahwa Pelaksanaan Pembatasan Sosial Berskala Besar meliputi: a. peliburan sekolah dan tempat kerja; b. pembatasan kegiatan keagamaan; c. pembatasan kegiatan di tempat atau fasilitas umum; d. pembatasan kegiatan sosial dan budaya; e. pembatasan moda transportasi; dan f. pembatasan kegiatan lainnya khusus terkait aspek pertahanan dan keamanan. Di dalam peraturan tersebut di jelaskan bahwa kegiatan keagamaan termasuk kegiatan yang juga dikenakan Pembatasan sosial berskala besar.

Penerapan kebijakan pembatasan sosial berskala besar oleh pemerintah nyatanya memang berdampak secara signifikan terhadap kehidupan masyarakat pada umumnya. Kegiatan-kegiatan yang melibatkan berkumpulnya orang banyak dibatasi baik dalam hal kegiatan perekonomian sampai dengan wilayah privat yaitu beribadah. Wabah Covid-19 yang ditetapkan sebagai pandemi menciptakan kedaruratan kesehatan bahkan kedaruratan lainnya sehingga menjadi masalah besar bagi pemerintah dan masyarakat. Penanganan yang dilakukan untuk mengatasi darurat kesehatan nyatanya tidak berbanding lurus dengan penanganan darurat ekonomi di masyarakat. Pemberlakuan ebijakan pembatasan sosial berskala besar oleh pemerintah direspon secara berbeda oleh masyarakat dan variatif beragam. Respon secara berbeda tersebut diperlihatkan oleh masyarakat untuk menunjukan proses perubahan hubungan sosial dan hukum yang disebabkan oleh faktor internal dan eksternal terjadi akibat Pandemi Covid 19. Perubahan sosial dan perubahan hukum memang tidak selalu berlangsung secara bersama-sama. Dalam keadaan-keadaan tertentu perkembangan hukum nampak tertinggal oleh perkembangan sosial masyarakat khususnya mengikuti perkembangan teknologi dan informasi memang membuat perkembangan hukum tertinggal jauh.

Kebijakan Pembatasan Sosial Berskala besar merupakan produk hukum yang mendorong terjadinya perubahan sosial, misalnya kualitas pola hidup sehat masyarakat yang dituntut untuk berubah secara mendasar. Hukum yang bersifat memaksa dan dilengkapi dengan instrumen sanksi mencoba merekayasa keadaan sosial masyarakat dengan menetapkan peraturan terhadap perbuatan yang boleh dan jika terjadi pelanggaran mengharuskan masyarakat bertanggung jawab atas perbuatan tersebut.

Relasi antara tidak sesuainya kehendak di buatnya sebuah peraturan dengan respon yang di perlihatkan oleh masyarakat seperti itu merupakan sebuah fenomena hukum. Hal ini berkaitan dengan objek kajian sosiologi hukum yang mendasarkan konsep hukum sebagai pengendalian social. $^{8}$ Dalam efektifitas penerapannya terdapat kondisi yang kontra produktif dengan tujuan-tujuan yang diharapkan dalam penerapan kebijakan tersebut. Penerapan kebijakan yang membatasi 


\section{Fastabiq: Jurnal Studi Islam}

ISSN 2723-0228

Volume 1 Nomor 2 Nopember 2020

rutinitas masyarakat termasuk dalam hal agama dengan menutup secara sementara rumah-rumah peribadatan seperti masjid untuk sholat berjamaah dan pelaksanaan sholat jum'at dirasakan oleh sebagian masyarakat sebagai sebuah anomi.

Interaksi sosial yang biasa dilakukan oleh masyarakat dalam kondisi normal bisa dilakukan dengan tatap muka dan terjadi secara langsung, kini beralih menuju dunia maya atau daring melalui pemanfaatan teknologi tentu saja secara tidak langsung menimbulkan jarak sosial yang lain. Sebagai homo socius kondisi pandemi yang menuntut masyarakat untuk menjaga jarak dengan sesama menyebabkan manusia kehilangan eksistensinya, dimana masyarakat diciptakan oleh manusia dan manusia merupakan produk dari masyarakat.

Berdasarkan latar belakang permasalahan di atas maka penelitian ini bertujuan untuk mengetahui hal-hal sebagai berikut:

a. Bagaimana dampak penerapan kebijakan pembatasan sosial berskala besar terhadap masjid dan pasar dikalangan masyarakat?

b. Bagaimana respon masyarakat penerapan kebijakan pembatasan sosial berskala besar terhadap masjid dan pasar dalam perspektif sosiologi hukum?

Penelitian ini bertujuan memberikan manfaat sebagai berikut:

a. Secara praktis tulisan ini dapat membantu menelaah dampak pengaruh penerapan kebijakan hukum yang dikeluarkan oleh pemerintah terhadap masyarakat.

b. Secara teoritis tulisan ini memberikan manfaat untuk menelaah respon masyarakat terhadap penerapan kebijakan hukum yang dikeluarkan oleh pemerintah.

\section{METODE PENELITIAN}

Metode yang digunakan dalam penelitian ini adalah studi pustaka dari berbagai kasus dalam artikel yang membahas bagaimana penerapan pelaksanaan Pembatasan sosial berskala besar dalam kondisi pandemi Covid-19 dengan menggunakan analisis kebijakan sosial. Objek kajian dalam penelitian ini adalah mengenai efektifitas aturan hukum berupa PSBB oleh pemerintah terhadap masyarakat yang terdampak Pandemi Covid-19, Kepatuhan masyarakat terhadap aturan hukum yang sedang berlaku dan implementasi aturan hukum tersebut di tengah-tengah masyarakat. Dalam penelitian hukum ini data Primernya adalah data yang diperoleh secara langsung di lapangan, sedangkan data sekundernya adalah data-data kepustakaan berupa berita yang mempunyai hubungannya dengan permasalahan yang diteliti. ${ }^{9}$ 


\section{PEMBAHASAN}

\section{Dampak Penerapan Kebijakan Pembatasan Sosial Berskala Besar Terhadap Masjid Dan Pasar Dikalangan Masyarakat}

Dalam hal ini Pandemi Covid-19 mengarahkan manusia untuk memberikan perhatian paling serius dan penting terhadap dampak yang ditimbulkan secara luar biasa. Dampak wabah Covid-19 nyatanya memang tidak hanya berimplikasi terhadap masalah kesehatan saja akan tetapi berdampak secara multi dimensi terhadap aspek-aspek sosial, ekonomi bahkan masuk pada aspek privat manusia yaitu agama.

Pemerintah yang menerapkan kebijakan pembatasan sosial berskala besar sebagai upaya responsif dan preventif terhadap pencegahan penularan virus covid direspon secara berbeda oleh masyarakat. Bahkan ditemukan sejumlah penolakan terhadap kebijakan tersebut. ${ }^{10}$ Seperti hasil survey yang di rilis oleh indo barometer dan RRI (Radio Republik Indonesia) di kutip dari halam Kompas.com yang menyatakan 32,8 \% menilai masyarakat belum mematuhi ketentuan Pembatasan Sosial Berskala Besar (PSBB) ${ }^{11}$. Mayoritas responden $65 \%$ menyatakan bahwa pelaksanaan PSBB telah di patuhi publik, sementara 2,3\% tidak menjawab dan tidak tahu, alasan terbesar ketidakpatuhan terhadap penerapan PSBB adalah karena tuntutan ekonomi (51\%). Alasan lainnya yaitu, masih banyak warga Muslim melaksanakan shalat Jumat (5,5 persen), kesadaran masyarakat masih rendah (3,4 persen), dan kurang sosialisasi (2,1 persen). Dari survey tersebut ternyata Pelaksanaan kegiatan keagamaan ternyata berkontribusi terhadap ketidakpatuhan penerapan PSBB walaupun tidak besar dan signifikan.

Kondisi anomi yang ditimbulkan akibat pandemi bahkan menimbulkan perbedaan pandangan para ulama dalam menyikapi cara beribadah masyarakat saat kondisi sedang tidak normal atau terjadi wabah penyakit. Dalam hal ini sebetulnya keberadaan masjid dan pasar bukan lah sesuatu yang terdampak langsung, melainkan karena efek domino dari pemberlakuan kebijakan yang dilakukan oleh pemerintah. Respon terhadap kebijakan tersebut nampak terlihat ketika masjid-masjid ditutup atau dibatasi kegiatannya akan tetapi pasar tradisional atau Pasar Modern tetap dibuka. Akibat dari kebijakan tersebut menyebabkan banyaknya respon dari masyarakat secara beragam terhadap kebijakan tersebut. ${ }^{12}$

Kebijakan PSBB tersebut merupakan bagian dari cara pemerintah untuk mengatur tata kehidupan masyarakat melalui penetapan hukum. Hukum memiliki peran dan fungsi mengubah masyarakat agar tidak terjadi kekacauan dengan tujuan untuk menciptakan ketertiban dan kemanfaatan di tengah-tengah masyarakat. Hukum sebagai Law is a tool of sosial enginering ( alat yang merekayasa masyarakat) merupakan teori yang dikemukaan oleh Roscoe Pound yang berarti hukum sebagai alat pembaharuan dalam masyarakat. dalam hal ini kebijakan PSBB diharapkan dapat berperan merubah nilai-nilai sosial dan membawa masyarakat ke arah yang lebih baik.

Dampak dari adanya pandemi membuat masyarakat yang terbiasa berkomunikasi dalam kehidupan sehari-hari, kemudian harus menahan diri untuk beberapa waktu bersosialisasi sehingga 
terjauh dari paparan virus corona. Pound menyatakan bahwa kontrol sosial diperlukan untuk menguatkan peradaban masyarakat manusia karena mengendalikan perilaku antisosial yang bertentangan dengan kaidah-kaidah ketertiban sosial. Hukum, sebagai mekanisme kontrol sosial, merupakan fungsi utama dari negara dan bekerja melalui penerapan kekuatan yang dilaksanakan secara sistematis dan teratur oleh agen yang ditunjuk untuk melakukan fungsi itu. Akan tetapi, Pound menambahkan bahwa hukum saja tidak cukup, ia membutuhkan dukungan dari institusi keluarga, pendidikan, moral, dan agama. Hukum adalah sistem ajaran dengan unsur ideal dan empiris, yang menggabungkan teori hukum kodrat dan positivistik. ${ }^{13}$

Reaksi penerapan kebijakan PSSB merupakan intrumen hukum yang ideal untuk ikut mengatur bagaimana kehidupan masyarakat di tengah pandemi Covid-19. Pengaruh kebijakan tersebut dirasakan sangat berdampak karena berhubungan dengan eksistensi manusia dengan agama. Menurut Erich Fromm bahwa kebutuhan manusia akan agama, berakar dalam kondisi dasar eksistensi spesies manusia. Manusia memerlukan objek pengabdian semacam agama agar dapat mengatasi eksistensinya yang terisolasi dengan semua keraguan dan ketidakmampuan menjawab arti hidup ${ }^{14}$. Eksistensi tersebut terganggu selama pandemi ketika mayoritas masyarakat mencari perlindungan kepada sesuatu yang transenden manakala mendapat tekanan kehidupan. Dalam kondisi pandemi Covid-19 terdapat potret kecil seperti mempertentangkan eksistensi antara masjid dan pasar. Kondisi seperti itu memang wajar karena pada sekiranya di bulan Juni saat pandemi terjadi umat islam berhadapan dengan menyambut bulan Ramadhan.

Relasi sosio-spasial antara masjid dan pasar dalam kondisi pandemi, memang tidak hanya menunjuk pada konsep "tempat" saja, melainkan menjelaskan kedalaman makna di dalam konfigurasi elemen fisik pembentuk ruang. fenomena sosial saat pemberlakuan Pembatasan Sosial yang berdampak terhadap masjid dan pasar, tidak hanya soal pertentangan tempat semata melainkan memiliki kedalaman makna yang lebih dalam untuk dipahami. Menelaah relasi masjid dan pasar sebagai objek salah satu objek kajian yang memberikan pengaruh terhadap perubahan sosial di tengah-tengah masyarakat memberikan makna bahwa relasi masjid dan pasar bukan lah semata urusan benda dan ruang kosong semata, namun memberikan makna dan fungsi, ketimpangan yang terjadi akibat munculnya anggapan bahwa masjid adalah tempat yang perlu di batasi untuk membatasi penularan virus sedangkan pasar tidak karena dianggap dapat menyelamatkan kondisi perekonomian yang sempat shutdown. Masjid dan pasar dalam arsitektur di artikan sebagai konsep place yaitu pengakuan akan adanya ruang kosong di antara konfigurasi elemen fisik, di mana manusia berada di dalamnya, beraktivitas, dan membangun hubungan maknawi dengan lingkungan.

Masjid dan pasar disebut sebagai "place as assemblage", yang melihat ruang arsitekturalnya sebagai wadah jalinan sosial masyarakat yang menggunakannya. Masjid merupakan wadah jalinan sosial yang memperkuat ikatan transenden antara manusia dengan Allah Swt, ikatan tersebut tersebut memberikan kekuatan kepada manusia yang secara kodrati lemah pada saat menerima tekanan yang bersifat ekternal, pada saat pandemi aktifitas yang dibatasi menyebabkan eksistensi 
manusia terganggu, akibat terserbut menimbulkan penolakan terhadap kebijakan yang dibuat tersebut.

Kerangka teori ini dimaksudkan untuk memudahkan dalam merekam fenomena "place" sekaligus memandu untuk menciptakan lingkungan yang lebih baik, dan dijabarkan sebagai:

1) Kekuasaan/hasrat: melihat bagaimana para pelaku dalam sebuah "place" mengembangkan kapasitasnya untuk mencapai tujuan dan mengendalikan pelaku lainnya.

2) Jalinan (assemblages): melihat jalinan sosial yang menggunakan "place".

3) Teritorialitas/segmentaritas: melihat bagaimana ruang diorganisasi berdasarkan kekuasaan/hasrat dari kelompok sosial yang menggunakannya.

\section{Respon Masyarakat Terhadap Penerapan Kebijakan Pembatasan Sosial Berskala Besar Terhadap Masjid Dan Pasar Dalam Perspektif Sosiologi Hukum.}

Kebijakan pembatasan sosial berskala besar diatur melalui Peraturan Pemerintah Nomor 21 Tahun 2020 tentang Pembatasan Sosial Berskala Besar dalam Rangka Percepatan Penanganan Covid-19 yang kemudian diturunkan dan di perkuat dalam Peraturan Menteri Kesehatan Nomor 9 Tahun 2020 tentang Pedoman PSBB. ${ }^{15}$ Penerapan kebijakan pembatasan sosial berskala besar yang berdampak sangat luas khususnya bagaimana interaksi antara masyarakat yang sedang menghadapi Pandemi Covid-19 terhadap pelarangan kegiatan masjid dan pasar sebagai upaya penanggulangan penyebaran Virus yang dikhawatirkan tidak terbendung dan menimbulkan banyak korban. Penerapan kebijakan tersebut direspon secara berbeda oleh masyarakat luas, perbedaan respon terhadap kebijakan tersebut dipengaruhi oleh beberapa faktor yaitu secara internal maupun eksternal.

Kebijakan mengenai Pembatasan Sosial berskala besar di indonesia untuk pertama kalinya diterapkan pada tanggal 10 April 2020 di Jakarta kemudian diikuti oleh beberapa daerah lainnya. Kebijakan yang diberlakukan selama masa pandemi tersebut diharapkan efektif dan menurunkan kurva Covid-19 yang terus meningkat. Hal tersebut kemudian yang membuat kondisi tarik menarik antara kebijakan yang diberlakukan dengan keberlakuan nilai-nilai yang hidup di masyarakat salah satunya adalah nilai-nilai agama.

Keberadaan kebijakan tersebut sebagai hukum yang diberlakukan dalam masyarakat sangatlah penting. Hadirnya kebijakan tersebut diperlukan karena subtansi hukum mengatur perilaku manusia. Hukum tidak terlepas dari masyarakat, begitupun sebaliknya, karena selain hukum pasif, hukum juga berfungsi aktif dalam mengontrol setiap tindakan individu dan selalu berusaha membawa masyarakat ke dalam suatu perubahan yang terencana. Hukum yang berlaku dalam masyarakat, pada dasarnya berasal dari masyarakat itu sendiri dan secara sengaja pula dibebankan kepadanya, agar masalah atau konflik dapat diminimalisirkan. Dalam kondisi pandemi pemerintah mengkategorikan kondisi pandemi sebagai darurat kesehatan, sehingga secara utilitis atau sosiologis kebijakan tersebut diharapkan tidak bertentangan dengan nilai-nilai yang hidup dalam masyarakat. 
Hukum yang dibuat seyogyanya mempunyai tujuan untuk menciptakan perdamaian, ketentraman dan ketertiban dalam masyarakat serta memberikan kepastian hukum.

Terlaksananya ketertiban dalam suatu masyarakat sangat ditentukan oleh beberapa faktor yaitu pertama struktur, kedua subtansi dan yang ketiga adalah budaya hukum. kesemuanya berorientasi bagaimana hukum diterapkan dalam masyarakat serta kesadaran masyarakat akan suatu aturan perlu di tingkatkan. Ketaatan serta kesadaran masyarakat terhadap hukum banyak ditentukan dengan berfungsinya suatu hukum, Sehingga fungsi hukum tidak hanya dilihat secara spesifiknya saja, tetapi dapat dilihat secara lebih luas atau universal. ${ }^{16}$ Hukum sebagai suatu aturan yang mengatur kehidupan masyarakat dan apabila dilanggar mendapat sanksi. menjatuhkan sanksi merupakan salah satu faktor yang mendorong untuk menaati suatu aturan, sehingga fungsi hukum juga dapat terimplementasikan dalam masyarakat. kesadaran hukum masyarakat kemudian terpengaruh oleh pandangan masyarakat yang berbeda-beda dalam merespon kebijakan pembatasan sosial berskala besar saat menghadapi pandemi covid 19. Tujuan dari pembatasan tersebut diharapkan secara langsung berimplikasi terhadap keamanan dan kesehatan masyarakat, hukum berlaku secara efektif jika hukum selaras dengan kesadaran masyarakat.

Dalam hal terjadinya pandemi bahwa hukum yang tertinggi adalah keselamatan masyarakat walaupun tentu saja berdampak kontradiktif terhadap berlangsungnya kehidupan masyarakat. Dampak diberlakukannya Pembatasan Sosial Berskala Besar, terutama berkaitan dengan kondisi perekonomian saat ini yang merosot drastis yang berdampak secara tidak langsung berbenturan nilai sosial dengan nilai religius. Kebijakan tersebut tentu saja bertentangan dengan pemenuhan kebutuhan masyarakat yang diharapkan dapat terpenuhi, dalam hal ini kebutuhan spiritual masyarakat pun di harapkan dapat terpenuhi juga, oleh karena demikian output kebijakan yang diharapkan adalah seimbangnya kehidupan masyarakat. Tujuan yang diharapkan demikian tersebut, sesuai dengan tujuannya terwujudnya ketertiban hukum dengan cara merekayasa masyarakat agar mematuhi protokol kesehatan. Sesungguhnya proses rekayasa sosial dengan menggunakan kebijakan penerapan pembatasan sosial berskala besar merupakan proses yang tidak terhenti pada pengukuran instrumen hukum yang tersedia.

Respon masyarakat yang bertentangan dengan pelaksanaan penerapan PSBB berhubungan dengan keyakinan nilai-nilai ajaran agama yang dianut oleh masyarakat selain dari pemenuhan kebutuhan yang harus tetap dipenuhi akibat dari roda ekonomi yang tidak berjalan. Masyarakat akhirnya mencoba menarik secara subjektif posisi antara masjid dan pasar dalam fungsi yang sama karena kebutuhan spiritual dan ekonomi menjadi sangat penting saat pandemic COvid 19 terjadi.

\section{SIMPULAN}

Kebijakan Pembatasan Sosial Berskala Besar yang dilakukan oleh pemerintah dalam menyikapi kasus Covid-19 merupakan langkah preventif menghadapi masa pandemic Covid 19. Relasi masjid dan pasar sebetulnya tidak dihadapkan secara berlawanan atau dipertentangkan, 


\section{Fastabiq: Jurnal Studi Islam}

ISSN 2723-0228

Volume 1 Nomor 2 Nopember 2020

Dalam hal ini relasi yang terjadi antara Masjid, Pasar dan Pemberlakuan PSBB merupakan dampak dari penerapan kebijakan yang terjadi pada saat masa pandemic berlangsung sehingga menimbulkan reaksi dari masyarakat. Respon masyarakat tersebut memperlihatkan terganggunya keseimbangan antara kepentingan spiritualitas (akhirat) dan kepentingan (duniawi) salah satunya masalah ekonomi.

Respon masyarakat terhadap pembatasan sementara terhadap kegiatan-kegiatan sosial seperti penutupan secara sementara kegiatan keagamaan di masjid dan rutinitas perekonomian dipasar berdampak seperti relasi kedunya dipertentangkan. Dampak tersebut terjadi secara alamiah karena dirasakan mengganggu nilai-nilai agama dan sosial masyarakat yang sudah lama dianut. Sehingga berdampak pada efektifitas kebijakan atau produk hukum yang berlaku di masyarakat. Batasan-batasan hukum tersebut di masa pandemi berhubungan dengan sifat hukum yang mengatur pola kehidupan masyarakat dengan aspek-aspek lain yang dalam hal ini berhubungan dengan kepentingan ekonomi dan kesehatan masyarakat menghadapi pandemi Covid 19. 


\section{ENDNOTES}

${ }^{1}$ https://islam.nu.or.id/post/read/99953/ini-alasan-allah-mencintai-masjid-dan-membenci-pasar
2 Kuntowijoyo, Budaya dan masyarakat, Yogyakarta : Tiara Wacana, 2006
${ }^{3}$ Dalmeri, Revitalisasi fungsi masjid sebagai Pusat ekonomi dan dakwah multicultural, Jurnal :
Wallisongo, 2014 hal 326
${ }^{4}$ Triana rosalina Noor, Fungsi sosial-ekonomi pasar tradisional (Studi tentang pasar Karah, Kec.
Jambangan, Kota Surabaya) Jurnal : ejournal.kopertais4 hal 2
5 www.alodokter.com dengan judul Virus Corona-Gejala, Penyebab dan mengobati di unduh pada tanggal 9 September 2020

${ }^{6}$ Physical distancing atau pembatasan fisik adalah salah satu langkah yang disarankan untuk mencegah penyebaran virus Corona. Tidak hanya saat di luar rumah, pemerintah bahkan menganjurkan agar cara ini juga dilakukan saat di dalam rumah.

7 https://www.kompas.com/tren/read/2020/03/12/113008565/timeline-wabah-virus-corona-terdeteksipada-desember-2019-hingga-jadi?page=all di unduh pada tanggal 9 September 2020

${ }^{8}$ Shalihah, Fithriatus, Sosiologi Hukum, Depok : Rajawali Pers, 2017, hal 60

${ }_{9}$ Ishaq, Metode Penelitian Hukum, 2017, Bandung : Alfabeta Bandung, hal 65

${ }^{10} \mathrm{https}: / /$ republika.co.id/berita/qaka6t318/ketika-umat-ramai-bertanya-kenapa-masjid masih-ditutup

${ }^{11}$ Survey yang dilakukan oleh RRI dan Indobarometer di lakukan selama 9-15 April 2020 dengan 400 responden di tujuh provinsi di indonesia yang di rilis di halaman Kompas.com dengan judul "Survei RRI dan Indo Barometer: 32,8 Persen Responden Menilai Masyarakat Belum Patuhi PSBB", https://nasional.kompas.com/read/2020/04/23/14351671/survei-rri-dan-indo-barometer-328-persenresponden-menilai-masyarakat-belum?page=all. Di unduh pada tanggal 22 Oktober 2020

${ }^{12} \mathrm{https}$ ://republika.co.id/berita/qakpo3409/kenapa-masjid-ditutup-mal-dibuka-ini-jawaban-mahfud

${ }^{13}$ Lathif, Nazaruddin, Teori hukum sebagai sarana/Alat untuk memperbaharui atau merekayasa masyarakat, Jurnal :Pakuan Law Review, 2017, hal 77

14 Dadang Kahmad, Sosiologi Agama (Potret agama dalam dinamika konflik, pluralisme dan ${ }_{15}$ modernitas), Bandung ; Pustaka Setia, 2011, hal 63

${ }_{15} \mathrm{https}: / /$ nasional.kompas.com/read/2020/04/10/18195851/jubir-pemerintah-penerapan-physicaldistancing-diperkuat-melalui-kebijakan.

${ }^{16}$ Haryanti, Tuti, Hukum dan Masyarakat, Jurnal : tahkim, 2014, hal 161 


\section{REFERENSI}

Dadang Kahmad, Sosiologi Agama (Potret agama dalam dinamika konflik, pluralisme dan modernitas), Bandung ; Pustaka Setia, 2011.

Dalmeri, Revitalisasi fungsi masjid sebagai Pusat ekonomi dan dakwah multicultural, Jurnal : Wallisongo, 2014

Haryanti, Tuti, Hukum dan Masyarakat, Jurnal : tahkim, 2014.

https://islam.nu.or.id/post/read/99953/ini-alasan-allah-mencintai-masjid-dan-membenci-pasar https://nasional.kompas.com/read/2020/04/10/18195851/jubir-pemerintah-penerapan-physicaldistancing-diperkuat-melalui-kebijakan.

https://republika.co.id/berita/qaka6t318/ketika-umat-ramai-bertanya-kenapa-masjid masih-ditutup https://republika.co.id/berita/qakpo3409/kenapa-masjid-ditutup-mal-dibuka-ini-jawaban-mahfud https://www.kompas.com/tren/read/2020/03/12/113008565/timeline-wabah-virus-corona-terdeteksipada-desember-2019-hingga-jadi?page=all

https://nasional.kompas.com/read/2020/04/23/14351671/survei-rri-dan-indo-barometer-328-persenresponden-menilai-masyarakat-belum?page=all

Ishaq, Metode Penelitian Hukum, 2017, Bandung : Alfabeta Bandung.

Kuntowijoyo, Budaya dan masyarakat, Yogyakarta : Tiara Wacana, 2006

Lathif, Nazaruddin, Teori hukum sebagai sarana/Alat untuk memperbaharui atau merekayasa masyarakat, Jurnal :Pakuan Law Review, 2017.

Shalihah, Fithriatus, Sosiologi Hukum, Depok : Rajawali Pers, 2017.

Triana rosalina Noor, Fungsi sosial-ekonomi pasar tradisional (Studi tentang pasar Karah, Kec. Jambangan, Kota Surabaya) Jurnal : ejournal.kopertais4

www.alodokter.com dengan judul Virus Corona-Gejala, Penyebab dan mengobati di unduh pada tanggal 9 September 2020 